\title{
Jurist-Diction
}

Volume 4 No. 2, Maret 202

\section{Entitas dan Eksekusi Intangible Assets Berupa Hak Cipta Milik Persero Firma Dalam Pemberesan Harta Pailit}

\author{
Herdian Putranto Adi \\ Herdianadi39@gmail.com \\ Universitas Airlangga
}

\begin{abstract}
How to cite:
Herdian Putranto Adi, 'Entitas dan Eksekusi Intangible Assets Berupa Hak Cipta Milik Persero Firma Dalam Pemberesan Harta Pailit' (2021) Vol. 4 No. 2 JuristDiction.
\end{abstract}

Histori artikel:

Submit 9 November 2020; Diterima 18 Desember 2020 Diterbitkan 5 Januari 2021.

DOI:

10.20473/jd.v4i2.25784

p-ISSN: 2721-8392

e-ISSN: $2655-8297$

\section{(c) (i) (2) (2)}

\begin{abstract}
Copy rights is one branch in the study of Intellectual Property rights. The purpose of copyright is an incentive for further creation for producers, promotors who taken risk for the marketing, and sales of creation and copy right has the power of moral right's and economy right's. In ythe study that will be discussed as to whether copyright is a wealth classification as boedel bankcruptcy, and speaking about the process of bankruptcy assets, how to execute assets with copyright. It is a theoretical research and doctrinal research, and it use conseptual approaches, statute approaches, and case approaches. As a result ini the study stating that copyright is a classification of bankruptcy property and that in the case its execution, the curator can use the strategy of going concern about the wealth.

Keywords: Copy right ; Bankruptcy; Amble Execution; Going Concern.
\end{abstract}

\begin{abstract}
Abstrak
Hak cipta merupakan salah satu cabang dalam kajian Hak Kekayaan Intelktual .Tujuan Hak Cipta sebagai perangsan (incentive) bagi penciptaan lebih lanjut bagi produser penerbit, promotor yang telah mengambil resiko guna pemasaran dan penjualan Ciptaan, serta Hak Cipta memiliki keberdayagunaan berupa moral right's dan economy right's. Dalam penelitian ini yang akan dibahas mengenai apakah Hak Cipta merupakan klasifikasi harta kekayaan sebagai boedel pailit, dan berbicara mengenai proses pemberesan harta pailit, bagaimana cara mengeksekusi intangible assets berupa Hak Cipta. Penelitian ini merupakan penelitian theoretical research dan doctrinal research, serta menggunakan pendekatan konseptual, pendekatan perundangundangan, dan juga pendekatan kasus. Hasil dalam penelitian ini, yakni menyatakan bahwa Hak Cipta merupakan klasifikasi harta pailit dan dalam rangka proses eksekusinya, kurator dapat menggunakan strategi going concern atas harta kekayaan tersebut.

Kata Kunci: Hak Cipta; Kepailitan; Eksekusi boedel pailit; Going concern.
\end{abstract}

Copyright $\odot 2021$ Universitas Airlangga

\section{Pendahuluan}

Dalam era globalisasi seperti ini memberikan implikasi akan kemajuan teknologi yang pesat, begitu juga dalam bidang ekonomi dan industry. Dengan adanya kemajuan teknologi ini membuat setiap pelaku usaha yang salah satunya 
perusahaan memiliki akses untuk melakukan hubungan kerja sama yang bersifat kontraktual ke berbagai pihak atau pelaku usaha lain, hingga lintas batas teritori.

Selain itu, dengan era globalisasi industri ini memberikan kesempatan bagi pelaku usaha untuk dapat lebih mendapatkan keuntungan dan juga modal usaha. Dalam hal usaha mendapatkan modal usaha, salah satunya adalah dengan mencari pinjaman dana berupa kredit kepada kreditur atau usaha pembiayaan yang lain.

Berbicara melakukan kredit kepada kreditur, tentu hal ini membawa angin segar berupa tambahan dana untuk menunjang operasional perusahaan. Dan dana tambahan ini berpotensi untuk membuat system operasional serta system keuangan perusahaan berjalan lancar.

Namun, ada pepatah yang mengatakan bahwa "utang adalah utang”,yang mana jika direlevansikan dengan bahasan ini maka apabila perusahaan yang selaku kreditor melakukan kredit kepada kreditur, tentunya debitor masih memiliki kewajiban untuk melunasi utang tersebut. Tentu sebelumnya, ketika hendak melakukan kesepakatan kredit, debitur dan kreditur sudah menentukan mengenai term and condition yang salah satunya adalah waktu jatuh tempo pelunasan utang.

Dan apabila si debitor terdapat telah lalai dalam melakukan pelunasan utang terlebih telah memenuhi unsur Pasal 2 Ayat (1) UUKPKPU yang isinya setidaknya tidak melunasi satu utang kepada kreditor yang telah jatuh waktu dan dapat ditagih, maka kreditur tersebut memiliki hak untuk mengajukan permohonan pailit kepada debitor tersebut ke Pengadilan Niaga.

Berbicara mengenai pengajuan permohonan pailit, maka apabila terbukti telah memenuhi unsur Pasal 2 Ayat (1) UUKPKPU maka Hakim Pengadilan Niaga dapat menjatuhkan putusan pailit kepada debitor dan nantinya akan bermuara kepada proses pemberesan harta pailit.

Dalam hal pemeberesan harta pailit, sudah memasuki ranah kewenangan kurator yang diawasi oleh hakim pengawas. Namun, dalam praktiknya kurator mengalami banyak kendala. Salah satunya apabila menghadapi aset yang tak berwujud (intangible assets) terkhusus berupa hak cipta. Apalagi ditambah perusahaan yang mengalami kepailitan berbenntuk badan usaha Firma (Fa). 
Tentu hal ini akan sangat rumit dan belum ada peraturan perundang-undangan yang mengatur lebih mengenai pemberesan intangible assets terkhusus berupa hak cipta.

Kesusahan yang dialami karena intangible assets berupa hak cipta berdasarkan UU 28 Tahun 2014 tentang Hak Cipta bersifat moral rights sehingga tidak dapat dialihkan kepada pihak lain, disisi lain berdasarkan UU.34 Tahun 2007 tentang Kepailitan dan Penundaan Kewajiban Pembayaran Utang setiap aset/harta kekayaan debitor yang dapat dinilai uang (salah satunya intangible assets) masuk dalam boedel pailit dan dapat digunakan untuk keperluan pelunasan passive debitor.

Sehingga hal ini menimbulkan pertanyaan, yaitu apakah intangible assets berupa hak cipta miliki persero firma (fa) dapat dimasukan ke dalam boedel pailit, selain itu jika intangible assets berupa hak cipta miliki persero firma (fa) dapat dimasukan ke dalam boedel pailit bagaimana proses pemberesan dan eksekusinya?

\section{Metode Penelitian}

Tipe penelitian yang digunakan ialah berupa Theoritical Research dan Doctrinal Research. Adapun yang dimaksud dengan Theoritical Research menurut Hutchinson ialah : "Research which fosters a more complete understanding of the conceptual bases of legal principles and of combined effects of a range of rules and peocedures that touch on a particular area of activity " (penelitian yang membantu menguraikan pemahaman yang lebih menyeluruh terkait dasar konseptual dari sebuah prinsip hukum dan campuran dampak dari berbagai aturan dan prosedur yang terkait pada suatu kegiatan). ${ }^{1}$

Sementara itu, Doctrinal Research didefinisikan sebagai : " Research which provides a systematic eksposisition of the rules governing a particular legal category, analyses the relationship between rules, eplain areas of difficulty and perhaps, predicts future development" ( penelitian yang menghasilkan pemaparan secara sistematis mengenai aturan yang mengatur kategori atau aspel hukum

\footnotetext{
1 Terry Hutchinson, Researching and Writing in Law ( Lawbook Co 2002).[8].
} 
tertentu, menganalisis hubungan antara aturan hukum, menjelaskan bidang yang sulit, dan mungkin memprediksi perkembangan selanjutnya). ${ }^{2}$

Pendekatan dilakukan secara normatif. Pendekatan terhadap masalah dilakukan melalui Statute Approach (pendekatan peraturan perundang-undangan), Comparative Approach (Pendekeatan Perbandingan) serta Conceptual Approach. Adapun yang dimaksud dengan Statute approach adalah dengan menelaah semua Undang-undang dan regulasi yang terkait dengan isu hukum yang sedang ditangani. ${ }^{3}$ Statute Approach dilakukan melalui analisis terhadap ketentuan yang termuat dalam Undang-undangan Nomor 28 Tahun 2014 tentang Hak Cipta, Undang-undang Nomor 37 Tahun 2004 tentang Kepailitan dan Penundaan Kewajiban Pembayaran Utang, Kitab Undang-undang Hukum Dagang, serta Kitab Undang-undang Hukum Perdata (untuk selanjutnya disebut Burgerlijk Wetboek atau disingkat dengan BW).

Comparative Approach yakni pendekatan yang dilakukan melalui studi perbandingan hukum. Perbandingan hukum disini merujuk pada kegiatan untuk membandingkan hukum suatu negara dengan hukum negara lain atau hukum dari suatu waktu tertentu dengan hukum yang lain. ${ }^{4}$ Adapun dalam penelitian ini menggunakan perbandingan hukum dengan negara Belanda dan Perancis mengingat memiliki sistem hukum yang sama dengan Indonesia, yaitu Civil Law System. Sehingga memudahkan dalam rangka membandingkan konsep dan praktik dalam menyelesaiakan isu hukum yang berhubungan dengan hak cipta dan kepailitan.

Pendekatan terakhir yang digunakan dlaam penelitian ini adalah Conceptial Apprpach atau pendekatan secara konseptual, yang digunakan untuk membangun konsep-konsep yang belum jelas atau tidak diterangkan di dalam Undang-undang. Pendekatan ini digunakan untuk merumuskan konsep "Hak Eksklusif" sebagai boedel pailit dalam tahap pemberesan harta kekayaan.

\footnotetext{
2 ibid.

3 Peter Mahmud Marzuki, Penelitian Hukum (Prenada Media 2005).[93].

4 ibid.[137].
} 


\section{Entitas Hak Cipta Sebagai Intangible Assets.}

Hak cipta merupakan salah satu cabang dalam kajian Hak Kekayaan Intelktual yang juga terpancar dari pengaturan Agreement on Trade-Related Aspects of Intellectual Property Rights, terjemahan Indonesia: “Aspek-Aspek Dagang yang Terkait dengan Hak atas Kekayaan Intelektual"). Perkembangan perlindungan dan pengaturan Hak Cipta mencakup 2 (dua) pendekatan yang dianut oleh negara dengan tradisi hukum Common Law System dan Civil Law System. Hak cipta dalam konteks ini adalah copyright atau right to copy. Copyright system memandang Hak Cipta sebagai instrumen ekonomi dan kebijaksnaan meningkatkan pengetahuan dan mendukung perkembangan sosial ekonomi.

Tujuan Hak Cipta sebagai perangsan (incentive) bagi penciptaan lebih lanjut bagi produser penerbit, promotor yang telah mengambil resiko guna pemasaran dan penjualan Ciptaan. Hal ini berpengaruh pula pada bidang yang dilindugi tidak hanya bidang penciptaan atau penerbitan buku, tetapi juga di bidang drama musik, pekerjaan artitstik dan settelah perkembangan teknologi meluas meliputi juga sinematografi, rekaman suara, penyiaran dan lain-lain. Dalam hal ini pencipta dapat orang alamiah (natural person) atau badan hukum (rechtperson). Dalam common law system mensyaratkan adanya perwujudan (fiksation) di samping keaslian (originality) dan kreativitas (creativity. Hak Cipta menurut common law system hanya mencakup hak ekonomi saja, sedangkan hak moral masih di pertanyakan. ${ }^{5}$

Negara dengan tradisi Civil Law System memiliki pendekatan author right system yang memberikan perlindungan pada Pencipta dan perlindungan bertitik tolak dari Pencipta lebih daripada perlindungan atas Ciptaan itu sendiri. ${ }^{6}$ Pendekatan Civil Law System ini tidak terlepas dari pandangan Hegel tentang HKI sebagai kekayaan (property) bahwa Hak Cipta adalah perwujudan dari eksistensi kepribdian (personality) untuk mana Pencipta eksis.

\footnotetext{
5 David Veyer, 'Moral Rights Yesterday, Today and Tomorrow' (2005) 7 International Journal of Law and Information Technology.[2].

6 Martin Sentfleben, Copyrightt, Limitations and Three Step Test in International and EC Copyright Law ( Kluwer Law 2003).[7].
} 
Tujuan Hak Cipta adalah memberikan penghargaan (reward) bagi si Pencipta dan ini merupakan argumen moral. Ada rumusan secara eksplisit hak-hak Pencipta yang dalam hal tertentu ada pembatasan (limitation) hak-hak Pencipta untuk penggunaan oleh pihak lain secara wajar. Pencipta harus seorang alamiah (natural person). Civil Law System mensyaratkan keaslian (originality) dan kreativitas (creativity) sebagai derajat yang sangat tinggi, sehingga mencerminkan kepribadian yang tercetak. Hak Pencipta mecakup dimensi hak ekonomi dan juga hak moral. ${ }^{7}$

Indonesia yang mewarisi tradisi hukum Civil Law System seharusnya titik tolak pengaturan Hak Cipta dari Hak Pencipa (Author Right System) dengan prinsip-prinsip dan karakter sebagaimana tersebut di atas. Di Indonesia selain UU. No. 19/2002 Tentang Hak Cipta ada beberaa isntrumen yang mengatur tentang pengaturan dan perlindungan utama dari Ciptaan asli (original) di bidang sastra (literary), drama (dramatic), musik dan seni (musical and artist works), serta pengaturan Hak Terkait dengan Hak Cipta (related right) yaitu:

a) TRIPs sebagai salah satu agenda Agreement on Establishing the World Trade Organization yang disahkan berdasarkan UU. No.7/1994;

b) The Berne Convention for the Protection of Literary and artistic Works sesuai Paris tekt 1971 (Berne Convention). ${ }^{8}$ (Berdasarkan Keputusan Presiden Nomor 18 tahun 1997);

c) The Rome Convention for The Protection of Performers Producers of Phonograms and Broadcasting Organization (yang ditunjuk oleh TRIPs dan diberlakukan sebagai basis minimal perlindungan);

d) World Intellectual Property Organization of Copyright Treaty (WCCT) berdasarkan Keppres No.19/1997;

e) The World Intellectual Property Organization of Performers and Phonograms Treaty ( WPPT) berdasarkan Keppres No.74/2004.

Mengingat Indonesia menganut tradisi hukum Civil Law System maka Indonesia menetapkan perlindungan Hak Cipta dalam dimensi Hak Moral dan Hak Ekonomi. Hak Moral (Moral right) memiliki keterkaitan yang lekat dengan perlindungan hukum Hak Cipta yang bersifat pribadi. Persyaratan Ciptaan yang berisifat pribadi harus memenuhi persyaratan keaslian (originality), berdasarkan

7 ibid.

${ }^{8}$ Keputusan Presiden Republik Indonesia (Keppres RI) Nomor 18 Tahun 1997 tentang Pengesahan Berne Convention for the protection of Literary and Artistic Works tanggal 17 Mei 1997. 
kemampuan pikiran, imajinasi (creativity) dan dalam bentuk yang khas (fiksation). Hal ini seseuai dengan teori hukum dalam Hak Cipta yang mengatur suatu standard perlindungan Hak Cipta (standard of copyright's ability) sebagai berikut: ${ }^{9}$

1. Originality: the word "originality".. Or the test of "originality", is not that the work to be novel or unique. Even a work based upon something already in public domain may weel be orignal;

2. Creativity: Creativity as a standard of copyrightability is to great degree simply measure of originality. Although a work that marely copies ekcatly a prior work may beeld not to be original, if the copy entails the independent creative judment of the author in its production, that creativity will render the work original;

3. Fiksation: A work is fixed in a tangible medium of expression when it's embodiment in a copy or phonerecord by or under the authority of authors., is sufficiently permanent or stable to permit to be porceived, reproduced, or otherwise communicated for a period of more than transitory duration. A work concisting of sound imager or both, that are being transmitted is fixed for purpose of this fixation of the work is being made simultaneously with this transmision.

Konsep Civil Law System sebagaimana yang diwarisi Indonesia mensyaratkan bahwa Ciptaan yang dilindungi Hak Cipta harus merupakan kreasi intelektual yang bersifat pribadi dengan memenuhi persyaratan keaslian dan kreativitas dalam derajat yang sangat tinggi. ${ }^{10}$

Syarat keaslian (originality) terkait dengan konsepsi Hak Cipta sebagai kekayaan (property). Ciptaan harus benar dari eksistensi Pencipta. Apa yang dapat dilindungi adalah milik pribadi. Menrut ketentuan Berne Convention, unsur keaslian (originality) merupakan hal esensial agar suatu Ciptaan dapat diberikan perlindungan Hak Cipta. Hal ini dapat ditunjukkan dalam Article 2 (3) Berne Convention sebagaimana diubah terakhir di Paris (1971) tersebut di atas. Penentuan

\footnotetext{
9 Eark W. Kintner and Jack Lahr, An Intelectual Property Law Primer ( Clark Boardman 2207).[364].

${ }^{10}$ Christop Antons, 'Indonesian Law : The First 50 Years, Intelectual Property Law Reform in Indonesia', Makalah University of Melbourne (Asian Law Centre 1995).[6].
} 
keaslian merupakan petunjuk untuk memastikan ruang lingkup kekayaan Pribadi dari Pencipta dalam isi Ciptaannya. Salah satu pemahaman keaslan (originality) pada Hak Cipta dalam konteks bahwa Hak Cipta melindungi ekspresi dari ide, informasi atau pemikiran ( dan bukan ide atau pemikiran itu sendiri) yang dituangkan dalam bentuk konkret. Hal ini lebih dipertegas dengan ketentuan Article 9(2) TRIPs di atas. Lebih lanjut mengenai keaslian dikemukakan oleh James Labore yaitu : "Thus originality for the purpose of Copyright Law is not originality of ideas or thought but originality in the executio of the particular from required to express such idea or thought". ${ }^{11}$ Dengan demikian, keaslian yang diminta adalah keaslian perwujudan dari ide, sehingga yang dilindungi sudah merupakan bentuk nyata suatu Ciptaan.

Persyaratan kreativitas (creativity) terkait dengan adanya kreasi intelektual pribadi, artinya Ciptaan dibentuk dengan cipta, karsa, dan rasa manusia. Bukan Ciptaan di luar manusia. Sedangkan persyaratan perwujudan (Fixation) merupakan konsep bentuk material (material form) yang merujuk pada suatu Ciptaan sebagai tujuan perlindungan hak cipta. Namun demikian, negara dengan tradisi Civil Law System tidak terlalu tergas dalam mensyaratkan adanya perwujudan.

Berdasarkan karakter pribadi dari Hak Cipta, maka Hak Moral merupakan pengakuan bahwa suatu ciptaan merupakan pengembangan kepribadian si Pencipta dam bahwa keteraitan antara Pencipta dan Ciptaannya harus di hargai. Dalam negara Civil Law System dinyatakan bahwa Hak Cipta memiliki dimensi Hak Moral, disamping Hak Ekonomi. Di Indonesia, hal tersebut di atur dalam pasal 24 UU. No. 19/2002.

Selanjutnya dalam dimensi Hak Ekonomi (Economy Right) hal ini terkait dengan pemanfaatan atau pengeksploitasian Ciptaannya sesuai dengan norma bahwa; "Copyright shall protect the author with respect to his intelectual and personal realtionship with his work and also with respect to utilization of this work"

Hak ekonomi sendiri diatur dalam ketentuan Berne Convnetion. Sedangkan di Indonesia Hak Ekonomi diatur dalam pasal 2 UU.No.19/2002. Jadi Hak Ekonomi

\footnotetext{
11 James Lahore, Copyright (Butterworth 1977).[80].
} 
(economy right) merupakan dimensi Hak Cipta yang memberikan nilai ekonomi dan pemanfaatan bagi si pemegang Hak Cipta. Konsep dimensi Hak Ekonomi dalam Hak Cipta sering dikaitkan dengan konsep harta kekayaan menurut hukum Indonesia. Konsep harta kekayaan menurut hukum Indonesia meliputi benda dan hubungan hukum untuk memperoleh benda tersebut. Dengan kata lain meliputi benda (zaak) dan perikatan (verbintenis). ${ }^{12}$ Harta kekayaan adalah benda milik seseorang yang memiliki nilai ekonomi. ${ }^{13}$ Lebih lanjut menurut pasal 499 BW pengerrtian benda meliputi barang (goods) dan hak (recht). Baik harta kekayaan maupun hak yang melekat di atasnya dakui dan dilindungi berdasarkan bukti yang sah. Dengan uraian di atas, maka Hak Cipta merupakan suatu lingkup dari harta kekayaan.

\section{Entitas Firma}

Selanjutnya mengenai Firma (dari bahasa Belanda venootschap onder firma; secara harafiah : perserikatan dagang antara beberapa perusahaan atau sering disebut $\mathrm{Fa}$, adalah sebuah bentuk badan usaha untuk menjalankan usaha antara dua orang atau lebih (disebut Firmant) dengan memakai nama bersama atau satu nama yang digunakan bersama-sama untuk memperluas usahanya. Menurut Manulang n(1975) persekutuan dengan firma adalah persekutuan untuk menjalankan perusahaan dengan memakai nama bersama. Jadi ada beberapa orang yang bersekutu untuk menjalankan suatu perusahaan. Nama perusahaan seperti umumnya adalah nama dari salah seorang sekutu. ${ }^{14}$

Firma atau sering juga disebut $\mathrm{Fa}$, adalah sebuah bentuk persekutuan untuk menjalankan usha antara dua orang atau lebih dengan memakai nama bersama. Firma (Fa) ialah sautu persekutuan antara dua orang atau lebih yang menjalankan badan usaha dengan nama bersama dengan mempunyai tujuan untuk membagi hasil yang di dapat dari persekutuan tersebut. Dalam mendirikan firma mempunyai anggota paling sedikit dua orang atau lebih. Semua anggota mempunyai tanggung

\footnotetext{
12 Van Apeldoorn, Pengantar Ilmu Hukum (Pradnya Paramita 1973).[63].

${ }_{13}$ Abdul Kadir Muhammad, Hukum Harta Kekayaan (Citra Aditya Bhakti 1994).[10].

14 M. Manulang, Pengantar Bisnis (Gajah Mada University Press 2002).[15].
} 
jawab terhadap sebuah perusahaan dan menyerahkan kekayaan pribadi sesuai yang tercantum di dalam akra pendirian Firma. Jika firma tersebut pailit, maka semua anggota (sekutu) harus bertanggung jawab sampai harta punya pribadi ikut dipertangguhkan. ${ }^{15}$

Dalam firma semua anggota bertanggung jawab sepenuhnya baik sendiri maupun bersama terhadap utang-utang perusahaan kepada pihak lain. Bila perusahaan mengalami kerugian akan ditanggung bersama, hingga harta kekayaan pribadi tiap sekutu. Firma dapat dibentuk oleh 2 (dua) orang atau lebih yang semuanya belum memiliki usaha. Pemilik firma terdiri dari beberapa orang yang bersekutu dan masing-masing anggota persekutuan mernyerahkan kekayaan pribadi sesuai yang tercantum dalam akta pendirian perusahaan. ${ }^{16}$

Firma bukan merupakan badan usaha yang berbadan hukum, karena tidak ada pemisahan harta kekayaan antara persekutuan dan pribadi sekutu-sekutu, setiap sekutu bertanggung jawab secara pribadi untuk keseluruhan. Tidak ada keharusan pengesahan akta pendirian oleh Menteri Hukum dan HAM, serta firma berakhir apabila jangka waktu yang telah ditetapkan dalam anggaran dasar telah berakhir. ${ }^{17}$

Tujuan dari firma sendiri adalah utuk memperluas usaha dan menambahkan midal agar lebih kuat dan mampu bersaing dengan perusahaan lain. Firma juga biasa disebut dengan Persekutuan (Partnership), sebab perusahaan yang dibentuk firma memang didirikan oleh orang-orang atau sekutu-sekutu sebagai pemilik dari firma. Dengan demikian pemilik firma biasa disebut anggota atau sekutu atau partner. Perusahaan dengan bentuk firma bis adijumpai pada berbagai jenis perusahaan, seperti perusahaan penerbitan, perusahaan perdagangan, perusahaan jasa, kantorkantor konsultan hukum, dan akutansi publik. ${ }^{18}$

Dasar hukum firma diatur dalam pasal 16 sampai dengan pasal 35 Kitab Undang-undang Hukum Dagang (KUHD). Jika direlevansikan dengan kasus

\footnotetext{
15 Johanes Ibrahim, Hukum Organisasi Perusahaan: Pola Kemitraan Dan Badan Hukum (PT. Refika Aditama 2006).[45].

16 ibid.

17 ibid.

18 ibid.
} 
atau pembahasan yang akan penulis tulis, maka persero-persero dalam firma memiliki tanggung jawab yang tidak terbatas dalam artian biaya operasional, biaya kepengurusan bahkan sampai jika firma mengalami kerugian, maka tiap persero wajib untuk mengerahkan harta kekayaan pribadinya kepada firma. Bahkan apabila firma mengalami pailit, maka tiap persero wajib mengerahkan sampai harta kekayaan pribadi dalam proses pemberasan boedel pailit. Atau dengan kata lain, pasti kurator juga akan menggugat pailit tiap persero firma untuk melaksanakan pemberesan harta firma yang telah dijatuhi pailit, dan dengan demikian harta kekayaan pribadi tiap persero juga masuk dalam lingkup pemberesan, termasuk aset-aset persero baik berwujud (tangible assets) dan tak berwujud (intangable assets) secara khusus seperti hak eksklusif dan dalam bahasan kali ini adalah hak cipta yang dimiliki salah satu persero.

\section{Eksekusi Aset Kekayaaan Firma berupa Hak Cipta milik Persero Firma}

Selanjutnya, mengenai Hukum Kepailitan adalah bidang hukum yang terkait dengan bidang hukum apapun, termasuk di dalamnya hukum perdata dan hukum kekayaan intelektual. Masalah kebendaan misalnya, diatur menurut Hukum Perdata yang berlaku di Indonesia, sebagaimana dinyatakan dalam pasal 499 KUHPerdata, dinyatakan bahwa yang dimaksud dengan benda adalah tiap-tiap barang dan tiaptiap hak yang dapat dikuasai oleh hak milik. Definisi yang termaktub dalam pasal 499 KUH Perdata tersebut adalah benda dalam arti nyata/materiil, sedangkan ada lagi jenis benda lainnya yaitu benda tidak nyata/imateriil/tidak terlihat, yang berwujud hak. Hal ini sesuai dengan klasifikasi benda menurut pasal $503 \mathrm{KUH}$ Perdata, yaitu penggolongan benda ke dalam kelompok benda berwujud dan benda tidak berwujud. Benda tidak berwujud yang biasanya merupakan jenis hak, salah satunya adalah hak kekayaan intelektual.

Hak Kekayaan Intelektual salah satu jenis benda, terkait dalam proses kepailitan, merupakan salah satu jenis benda yang dapat dipergunakan sebagai bagian dari asset dalam proses pembayaran hutang-hutang debitor kepada kreditor. Intangible Asset adalah bagian dari harta pailit. Pasal 1131 menyatakan bahwa: 
"Segala kebendaan si berutang, baik yang bergerak maupun tak bergerak, baik yang sudah ada, maupun yang baru akan ada di kemudian hari, menjadi tanggungan untuk segala perikatan perseorangan". Kata "segala" atau "seluruh" kebendaan debitor artinya tanpa terkecuali merupakan tanggungan untuk segala perikatan yang dibuat oleh debitor tersebut. Selanjutnya, pasal 1132 KUH Perdata menyatakan: "Kebendaan tersebut menjadi jaminan bersama-sama bagi semua orang yang mengutangkan padanya, pendapatan penjualan benda-benda itu dibagi-bagi menurut besar kecilnya piutang masing-masing, kecuali apabila di antara para berpiutang itu ada alasan-alasan yang sah untuk didahulukan”. Pasal 1132 KUH Perdata mengatur bahwa hasil penjualan barang-barang milik debitor dibagi menurut perbandingan piutang masing-masing kecuali bila di antara para kreditor itu ada alasan-alasan sah untuk didahulukan. Untuk menentukan alasan yang sah didahulukan merujuk pada pasal 1133 KUH Perdata yang mengatur bahwa hak untuk di dahulukan di antara para kreditor bersumber pada hak istimewa, pada gadai, dan pada hipotek.

Permasalahan yang terjadi adalah kurator selaku pihak yang melakukan pengurusan dan pemberesan harta pailit tidaklah mudah dalam melakukan tugasnya ketika bertemu dengan jenis-jenis aset yang tidak berwujud. Aset semacam ini wajib dinilai terlebih dahulu oleh Apresiasi (penilai) yang diakui atau bersertifikasi. Nantinya akan diketahui berapa nilai sesungguhnya dari jenis HaKI tertentu, dengan mempertimbangkan pada kemanfaatannya bagi pribadi tersebut dan nilai pasar. Kendala yang dihadapi kurator di dalam memaksimalkan HaKI terkhusus Hak Cipta saat kepailitan, antara lain yang pertama adalah HaKI tidak laku dijual. Seharusnya seluruh harta debitor wajib dijual pada masa pemberesan dan dibagikan kepada para kreditor tanpa terkecuali, namun ada jenis HaKI yang sulit dijual karena perlindungannya melekat sepenuhya pada si pencipta atau pemegang Hak Cipta. Hak Cipta berdasar pasal 29 UU. 28 tahun 2014 adalah seumur hidup. ${ }^{19}$ Pasal 29 UU.28/2014 tentang Hak Cipta menyatakan bahwa hampir semua jenis perlindungan hak cipta adalah berlaku selama hidup Pencipta dan terus berlangsung

\footnotetext{
19 Pasal 29 Undang-undang No. 28 tahun 2014 tentang Hak Cipta (Lembaran Negara Republik Indonesia Tahun 2014 Nomor 266).
} 
hingga 50 (lima puluh ) tahun setelah Pencipta meninggal dunia. Dari sini kita bisa membayangkan betapa perlindungan Hak Cipta melekat pada diri si Pencipta.

Hal ini tentu menimbulkan kesimpulan bahwa Hak Cipta bila dipandang dari segi dimensi Hak Ekonomi (economy right) merupakan lingkup harta kekayaan yang masuk dalam pengurusan dan penyelesaian harta pailit. Sedangkan, apabila kita melihat dalam segi Hak Moral (moral right) maka Hak Cipta eksistensinya melekat pada si Pencipta dan sangat mustahil untuk dipisahkan, lantas bagaimana status Hak Cipta apakah tetap masuk dalam klasifikasi harta pailit?.

Masalah kurator tidak hanya sebatas itu saja, perlu kita ingat bahwa Hak Cipta tidak memerlukan pendaftaran dalam hal si Pencipta mendapat perlindungan. Namun, bukan berarti si Pencipta tidak perlu mendaftarkan, si Pencipta dapat mendaftarkan dalam motivasi sebagai aspek bukti atau legalitas apabila terdapat pelanggaran Hak Cipta dan dapat dijadikan acuan sebagai permintaan kompensasi atas pelanggaran tersebut. Hal ini perlu diperhatikan kurator apabila Hak Cipta yang diurus tersebut sedang dalam sengketa dengan pihak ketiga. Hal ini mengingat dan mempertimbangkan bahwa semua perkara yang dijatuhkan terhadap debitor pailit sejak kepailitan dijatuhkan dinyatakan gugur demi hukum (pasal 29 UUKPKPU), ${ }^{20}$ maka tidak jelaslah siapa yang disebut sebagai pemilik yang sah secara pandangan rezim hukum Hak Cipta. Dan Hak Cipta yang dalam kondisi seperti ini tentu tidak dapat dinyatakan semata-mata sebagai bagian dari budel milik debitor pailit.

Selain itu, dalam hal pemberasan harta pailit apakah ada proses prioritas dalam pemberesan harta pailit, maksudnya kita mengingat dalam bahasan ini bahwa debitor pailit adalah tiap persero dari suatu firma dengan harta kekayaan pribadi persero masing-masing. Pertanyaanya apakah kurator memiliki diskresi untuk mendahulukan pemberesan harta pailit yang dibedakan berdasarkan wujud harta kekayaan, dalam hal ini apakah harta kekayaan dalam wujud hak eksklusif berupa hak cipta akan dilakukan sebagai penutup dalam pemberesan jika tidak cukup harta yang dibereskan atau juga diperlakukan sama dengan harta yang berwujud.

20 Pasal 29 UU. No. 37 tahun 2004 tentang Kepailitan dan Penundanan Kewajiban Pembayaran Utang (Lembaran Negara Republik Indonesia Tahun 2004 Nomor 131). 
Selanjutnya, dalam pembahasan ini yang menjadi debitor pailit adalah Firma atau persero-persero firma yang mana bertanggung jawab hingga harta kekayaan pribadi. Lantas bagaimana pembagian tanggung jawab dalam pemberesan harta kekayaan pribadi tiap-tiap persero yang memiliki hak eksklusif dalam bentuk hak cipta.

Dalam hal ini dalam proses pemberesan harta pailit, tentunya Kurator menerapkan prinsip efektifitas dan efisiensi. Kedua prinsip tersebut, konkritnya berupa tindakan Kurator berupa melakukan pemberesan aset Firma yang mudah untuk dieksekusi terlebih dahulu dan pada praktiknya aset yang mudah untuk dieksekusi adalah aset yang berwujud (tangible assets) baik barang bergerak maupun barang yang tidak bergerak yang memiliki nilai ekonomis.

Adapun apabila keseluruhan aset berwujud (tangible assets) milik Firma (Fa) telah habis dan terbukti masih terdapat utang yang harus dilunasi, maka Kurator dengan hak dan kewenangannya dapat memaksa untuk setiap persero Firma (Fa) secara tanggung renteng untuk bertanggun jawab dalam pelunasan utang Firma (Fa), dengan kata lain bertanggung jawab sampai pada harta kekayaan pribadi.

Dan apabila ditemukannya bahwa suatu persero Firma $(\mathrm{Fa})$ memiliki harta berupa intangible assets dalam bentuk hak cipta, maka sesuai dengan prinsip economy right's maka aset tersebut bernilai ekonomi dapat digunakan dalam pemeberesan harta pailit. Mengingat hak cipta juga memiliki value moral right's maka Kurator dengan hak dan kewenangannya dapat mengajukan going concern kepada Pengadilan Niaga terhadap intangible assets berupa hak cipta milik persero Firma $(\mathrm{Fa})$ yang mana hasil going concern tersebut akan menghasilkan materi dalam bentuk uang dan kemudian dapat digunakan dalam rangka pemberesan harta pailit.

\section{Kesimpulan}

Sesuai dengan bahasan di atas, maka Hak Cipta dikualifikasikan sebagai harta kekayaan dalam boedel pailit. Hal ini didasarkan atas dasar konsep dimensi Hak Ekonomi dalam Hak Cipta sering dikaitkan dengan konsep harta kekayaan menurut hukum Indonesia. Konsep harta kekayaan menurut hukum Indonesia meliputi benda dan hubungan hukum untuk memperoleh benda tersebut. Dengan 
kata lain meliputi benda (zaak) dan perikatan (verbintenis). Harta kekayaan adalah benda milik seseorang yang memiliki nilai ekonomi. Lebih lanjut menurut pasal 499 BW pengerrtian benda meliputi barang (goods) dan hak (recht). Baik harta kekayaan maupun hak yang melekat di atasnya dakui dan dilindungi berdasarkan bukti yang sah. Dengan uraian di atas, maka Hak Cipta merupakan suatu lingkup dari harta kekayaan.

Dan berbicara bagaimana cara mengeksekusi intangible assets berupa hak cipta milik persero Firma (Fa) yaitu dengan cara Kurator dengan hak dan kewenangannya dapat mengajukan going concern kepada Pengadilan Niaga terhadap intangible assets berupa hak cipta milik persero Firma $(\mathrm{Fa})$ yang mana hasil going concern tersebut akan menghasilkan materi dalam bentuk uang dan kemudian dapat digunakan dalam rangka pemberesan harta pailit.

\section{Daftar Bacaan}

\section{Buku}

Abdul Kadir Muhammad, Hukum Harta Kekayaan (Citra Aditya Bhakti 1994).

Eark W. Kintner and Jack Lahr, An Intelectual Property Law Primer ( Clark Boardman 2007).

James Lahore, Copyright (Butterworth 1977).

Johanes Ibrahim, Hukum Organisasi Perusahaan: Pola Kemitraan Dan Badan Hukum (PT. Refika Aditama 2006).

Martin Sentfleben, Copyrightt, Limitations and Three Step Test in International and EC Copyright Law ( Kluwer Law 2003).

M. Manulang, Pengantar Bisnis (Gajah Mada University Press 2002).

Peter Mahmud Marzuki, Penelitian Hukum (Prenada Media 2005).

Terry Hutchinson, Researching and Writing in Law ( Lawbook Co 2002).

Van Apeldoorn, Pengantar Ilmu Hukum (Pradnya Paramita 1973). 


\section{Jurnal}

David Veyer, 'Moral Rights Yesterday, Today and Tomorrow' (2005) 7 International Journal of Law and Information Technology .

\section{Makalah}

Christop Antons, 'Indonesian Law : The First 50 Years, Intelectual Property Law Reform in Indonesia', Makalah University of Melbourne (Asian Law Centre 1995).

\section{Perundang-undangan}

Kitab Undang-undang Hukum Perdata (Staadsblad No.23 tanggal 30 April 1847).

Kitab Undang-undang Hukum Dagang (Staadsblad No.23 tanggal 30 April 1847).

Undang-undang Nomor 28 Tahun 2014 tentang Hak Cipta (Lembaran Negara Republik Indonesia Tahun 2014 Nomor 266).

Undang-undnag Nomor 37 Tahun 2004 tentang Kepailitan dan Penundaan Kewajiban Pembayaran Utang (Lembaran Negara Republik Indonesia Tahun 2004 Nomor 131).

Keputusan Presiden Republik Indonesia (Keppres RI) Nomor 18 Tahun 1997 tentang Pengesahan Berne Convention for the protection of Literary and Artistic Works tanggal 7 Mei 1997. 